\section{LATE INQUEST AT THE LONDON HOSPITAL.}

\section{To the Editor of The LANcet.}

SIR,-On perusing your LANCET of the last week, I observed the particulars of a case from the London Hospital, which was evidently in itself of no particular interest, but the intention of which was manifestly to throw blame on a gentleman whose general character at the above institution would in itself fully refute the truth of such aspersions. On that account, I do not intend to enter into any lengthened argument upon the injustice of reporting cases so as to give them a false colouring; but shall merely say, in allusion to the present instance, that a gentleman of this hospital, who was present at the inquest on the deceased mentioned in the case, declared to me, that the wife felt fully satisfied with the attention paid immediately Mr. Andrews arrived himself, and the patient, whilst alive, had expressed himself in the most sincere terms of gratitude for the humanity and kindness paid to him by that gentleman; but the only ground of their complaint was founded on neglect experienced at his first arrival at the hospital, from the fact of his not having his splints removed for several days, which they ignorantly construed into neglect. Such being this gentleman's statement, and, from my own observance, during a period of more than four years of Mr. Andrews's universal attention to his patients in the London Hospital, I have deemed il my duty to thus publicly refute, as far as lies in my power, aspersions which are both illiberal and unjust.

$$
\text { I am, Sir, }
$$

Yours most respectfully,

\section{September 24th, 1833.}

J. Cíocome.

We readily give insertion to $\mathrm{Mr}$. Crócome's note; but he ought not to bring a charge of inaccuracy against a reporter, without specifying the circumstances on which that charge is founded. Until Mr. Crocome can point out errors in the report to which he objects, it will be considered correct. The report itself having been a mere statement of facts, a deviation from the truth must have amounted to falseñood rather than "false colouring:" The remarks at the conclusion were written by the Editor.-Eo. L.

\section{GUY'S FIOSPITAL.}

To the Editor of THE LANCET.

Sir,-A case of fracture of the jaw is now in this hospital, which was unattended to by any surgeon or competent attendant for rwenty-four hours. Ascertain particulars. An important operation also has just been performed here before three pupils only. Your obedient servant,

Borough, Sept. 25 th, 1833. Clemens.

** We have ascertained the facts,-if our correspondent alludes to the coal-porters' and lithotomy cases,-and they shall appear next week. This week we have not room for them.

HOSPITAL LIBRARIES.

\section{To the Editor of The LANCET.}

SIR,-I feel satisfaction in being able to reply in the affirmative to the sensible and benevolent inquiry of your correspondent Mr. Hytch, with regard to hospital libraries. Among other provisions made with $a$ view to the religious edification and consolation of the patients of the London Hospital, there is a library of upwards of 400 volumes, instituted more than ten years ago by the present chaplain, expressly for the use of the patients. I am, Sir, your obedient servant,

London, Sept. 19th, 1833.

A Governor.

* * The libraries of invalids ought not to be confined to works solely on religious subjects.

\section{IYQUEST BEFORE A NON-MEDICA CORONER.}

\section{To the Editor of THE LANCET.}

Srk,-I beg leave to trouble you with an addition to your former sketches of the manner in which inquests are conducted by non-medical coroners.

On Saturday, the 14 th inst., I was called upon to visit, professionally, Ann Harman, of No. 11, Nursery Row, Walworth. I found her warm, but pulseless, and dead. The fatal event had occurred almo: immediately after an ejection of blood had taken place from her stomach. An inquest was held or the 17 th, and being summoned by the coroner, I attended, when the following dialogue took place. I term it a " dialogue," for the ccroner did not think it necessary that 1 should be sworn-such is the looseness with which 